
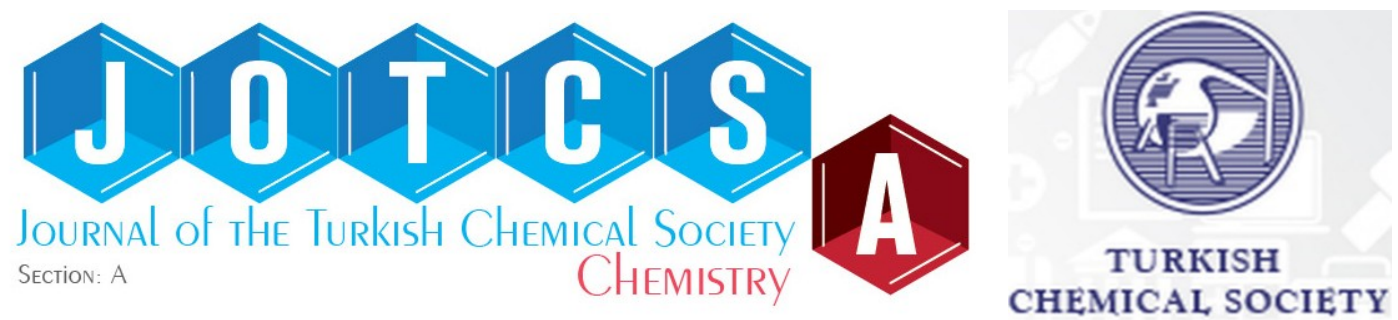

\title{
SYNTHESIS, ANTIBACTERIAL ACTIVITY AND DOCKING STUDIES OF BENZYL ALCOHOL DERIVATIVES
}

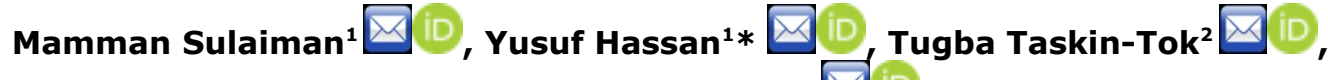 \\ Xavier Siwe Noundou ${ }^{3}$ \\ ${ }^{1}$ Umaru Musa Yar'adua University, Faculty of Natural and Applied Sciences, Department of Chemistry, \\ Katsina, Nigeria. \\ ${ }^{2}$ Gaziantep University, Faculty of Arts and Sciences, Department of Chemistry, Gaziantep, Turkey. \\ ${ }^{3}$ Rhodes University, Faculty of Science, Department of Chemistry, Grahamstown, South Africa.
}

Abstract: Benzyl alcohol derivatives were synthesized, and characterized using NMR and FTIR spectroscopic techniques. For the first time, the antibacterial activities of the synthesized compounds were examined using disc diffusion method by measuring the diameter of the zones of inhibition against Staphylococcus aureus and Pseudomonas aeruginosa. The results demonstrated that the activity was concentration dependant, and that the compounds were generally potent against $P$. aeruginosa. Only two of the compounds were active against $S$. aureus. In terms of broad spectrum activity, compound $\mathbf{2 d}$ (35 $\mathrm{mm}$ ) was found to exhibit a promising efficacy which surpassed that of the standard drug (amoxicillin). The binding of compounds 2a-e to the glucosamine-6-phosphate synthase (GlcN-6-P) active-site revealed that all the synthesized compounds fitted into the GlcN-6-P active-site receptor cavity, exhibited potential hydrogen-bonding interactions with the proximal amino acid residues and aligned similar to amoxicillin. Interestingly, it has been found that the most active compound, $2 \mathbf{d}$ also appeared to have a relatively low binding energy $(-52.8901 \mathrm{kcal} / \mathrm{mol})$.

Keywords: Benzyl alcohol derivatives, antibacterial activity, docking studies, glucosamine-6-phosphate synthase.

Submitted: February 21, 2020. Accepted: May 10, 2020.

Cite this: Sulaiman M, Hassan Y, Taşkın-Tok T, Noundou XS. SYNTHESIS, ANTIBACTERIAL ACTIVITY AND DOCKING STUDIES OF BENZYL ALCOHOL DERIVATIVES. JOTCSA. 2020;7(2):481-8.

DOI: https://doi.org/10.18596/jotcsa.692113.

*Corresponding author. E-mail: (yusuf.hassan@umyu.edu.ng), Tel: (+234 803062 1278).

\section{INTRODUCTION}

The continuous increase in the antibiotics resistance and the attendant scarcity of new antimicrobial agents is arguably one of the major challenges in public health today, especially in the developing countries where up to one-half of deaths are attributed to infectious diseases (1-4). This could particularly be seen in the level of antibiotics resistance associated with a number of staphylococcus species which causes respiratory and skin infections, as well as pseudomonas species which are also responsible for the gastrointestinal and urogenital diseases (5). For instance, the clinical isolates of staphylococcus aureus - the leading cause of nosocomial infections - are becoming resistant to a range of popular antimicrobial agents such as vancomycin, trimethoprim-sulfamethoxazole, chloramphenicol, erythromycin, clindamycin, ciprofloxacin, penicillin, amikacin, tobramycin, and gentamicin (6).

In an attempt to address the aforementioned concerns, a number of workers have reported various bioactive molecules built around some promising scaffolds and assessed their antibacterial or antimicrobial potentials. These includes nitroimidazole derived oxazolidinones (7), 
ciprofloxacin derivatives (8-11), icariin derivatives (12), 1-monolaurin (13), (E)-stilbene derivatives (14), benzimidazole-incorporated sulfonamide analogues (15), chalcone derivatives (16), 3phenyl-1-methylquinolin-2-one derivatives (17), oxysterols (18), 2-thiazolylimino-5-arylidene-4thiazolidinones (19), sulfonamide and carbamate derivatives of 5-Nitro- $1 \mathrm{H}$-indazole (20), polyfluorinated 4-thiazolidinone and aaminophosphonic acid derivatives (21). Interestingly, we have noted a known bioactive scaffold that aparently escaped the attention of workers - benzyl alcohol.

Benzyl alcohol (Figure 1) is an aromatic alcohol commonly found in various essential oils such as jasmine, ylang-ylang, and hyacinth (22). Due to its antibacterial and antifungal activities, it is widely used as an ingredient in the manufacture of soaps, topical creams, skin lotions, shampoos, and facial cleansers. Unfortunately however, benzyl alcohol has been reported to be a contact allergen (23). It thus prompted us in this work to prepare benzyl alcohol derivatives in order to evaluate their structure activity relationships with the aim of developing lead compounds that could offer safe and efficacious oral or topical antibacterial agents.<smiles>OCc1ccccc1</smiles>

Figure 1. Structure of benzyl alcohol.

\section{EXPERIMENTAL SECTION}

\section{Materials}

All reagents and solvents were purchased from Aldrich and used as received. ${ }^{1} \mathrm{H}$ and ${ }^{13} \mathrm{C}$ NMR spectra were recorded on a Bruker AVANCE 400 spectrometer. IR spectra were recorded on a Perkin-Elmer FT-IR Spectrum BX spectrophotometer. Melting points were determined on an Electrothermal melting point apparatus and are uncorrected.

\section{Methods}

\section{Chemistry}

General Procedure for the preparation of benzyl alcohol derivatives ( $2 a-e)$

The aldehydes $(13.2 \mathrm{mmol})$ were placed in a 250 $\mathrm{mL}$ round bottom flask containing ethanol $(4 \mathrm{~mL})$ and stirred at room temperature to obtain homogenous solutions. The resulting solutions were cooled on an ice bath prior to the addition of the reducing agent. Subsequently $\mathrm{NaBH}_{4} \quad(13.2$ mmol) dissolved in $1 \mathrm{M} \mathrm{NaOH}(3.8 \mathrm{~mL}$ ) was slowly added over a period of 10 minutes. The resulting mixture was stirred at room temperature for 10 minutes after which it was cooled and then treated with $6 \mathrm{M} \mathrm{HCl}$ dropwise until the evolution of $\mathrm{H}_{2}$ gas stopped. The $\mathrm{pH}$ was checked to make sure the solution was acidic, and further stirred for another 10 minutes to allow the appropriate product to precipitate. The products were collected by filtration, washed twice with ice-cold water and then transferred to a dry piece of filter paper and air dried. But in the case of compound $\mathbf{2 d}$, the crude mixture was extracted with chloroform which after evaporation afforded the product as a filmlike solid.

\section{4-hydroxy-3-methoxybenzyl alcohol, 2a}

White powder, 93\% yield, mp $112-114^{\circ} \mathrm{C}$. ${ }^{1} \mathrm{HNMR}$ $\left(400 \mathrm{MHz}, \mathrm{DMSO}_{4}-\mathrm{d}_{6}\right) \delta \mathrm{ppm} 3.71\left(3 \mathrm{H}, \mathrm{s}, \mathrm{OCH}_{3}\right)$, $4.37\left(2 \mathrm{H}, \mathrm{s}, \mathrm{CH}_{2}\right), 5.14(1 \mathrm{H}, \mathrm{s}, \mathrm{OH}), 6.70(2 \mathrm{H}, \mathrm{d}, \mathrm{J}$ $=4, \operatorname{Ar}-\mathrm{H}), 6.88(1 \mathrm{H}, \mathrm{s}, \operatorname{Ar}-\mathrm{H}), 8.88(1 \mathrm{H}, \mathrm{s}, \operatorname{Ar}-$ $\mathrm{OH}) ;{ }^{13} \mathrm{CNMR}\left(100 \mathrm{MHz}, \mathrm{DMSO}_{4}-\mathrm{d}_{6}\right) \delta \mathrm{ppm} 39.52$, 55.80, 63.36, 111.32, 1115.35, 119.51, 133.72, $145.54,147.67$; IR $3503,1509,1259 \mathrm{~cm}^{-1}$.

\section{4-hydroxybenzyl alcohol, 2b}

White powder, $87 \%$ yield, $\mathrm{mp} 260-265^{\circ} \mathrm{C} ;{ }^{1} \mathrm{HNMR}$ $\left(400 \mathrm{MHz}, \mathrm{DMSO}_{4}-\mathrm{d}_{6}\right) \delta \mathrm{ppm} 4.37\left(2 \mathrm{H}, \mathrm{s}, \mathrm{CH}_{2}\right)$, $5.07(1 \mathrm{H}, \mathrm{s}, \mathrm{OH}), 6.71(2 \mathrm{H}, \mathrm{d}, \mathrm{J}=8, \mathrm{Ar}), 7.11$ $(2 \mathrm{H}, \mathrm{d}, \mathrm{J}=8, \mathrm{Ar}), 9.36(1 \mathrm{H}, \mathrm{s}, \mathrm{Ar}-\mathrm{OH}) ;{ }^{13} \mathrm{CNMR}$ $\left(100 \mathrm{MHz}, \mathrm{DMSO}_{4}-\mathrm{d}_{6}\right) \delta \mathrm{ppm} 39.52,63.09,63.12$, $115.10,115.12,128.43,128.46,132.94,156.41$, 156.42; IR 3377, $1513,1233 \mathrm{~cm}^{-1}$

\section{4-nitrobenzyl alcohol, 2c}

Yellow powder, $93 \%$ yield, mp $131-134^{\circ} \mathrm{C} .{ }^{1} \mathrm{HNMR}$ $\left(400 \mathrm{MHz}, \mathrm{DMSO}_{4}-\mathrm{d}_{6}\right) \delta \mathrm{ppm} 3.56\left(2 \mathrm{H}, \mathrm{s}, \mathrm{CH}_{2}\right)$, $5.61(1 \mathrm{H}, \mathrm{s}, \mathrm{OH}), 7.57(2 \mathrm{H}, \mathrm{d}, \mathrm{J}=8, \mathrm{Ar}), 8.17$ $(2 \mathrm{H}, \mathrm{d}, \mathrm{J}=4, \mathrm{Ar}) ;{ }^{13} \mathrm{CNMR}\left(100 \mathrm{MHz}, \mathrm{DMSO}_{4}-\mathrm{d}_{6}\right) \delta$ ppm 39.52, 62.21, 123.49, 127.25, 148.50, 150.89 IR $3503,1505,1230 \mathrm{~cm}^{-1}$

\section{4-methoxybenzyl alcohol, 2d}

Film-like white solid; $94 \%$ yield; $\mathrm{mp} 212-215^{\circ} \mathrm{C}$; ${ }^{1} \mathrm{HNMR}\left(400 \mathrm{MHz}, \mathrm{DMSO}_{4}-\mathrm{d}_{6}\right) \delta \mathrm{ppm} 3.71(3 \mathrm{H}, \mathrm{s}$, $\left.\mathrm{OCH}_{3}\right), 4.40\left(2 \mathrm{H}, \mathrm{s}, \mathrm{CH}_{2}\right), 5.15(1 \mathrm{H}, \mathrm{s}, \mathrm{OH}), 6.87$ $(2 \mathrm{H}, \mathrm{d}, J=8, \mathrm{Ar}), 7.22(2 \mathrm{H}, \mathrm{d}, J=8, \mathrm{Ar}) ;{ }^{13} \mathrm{CNMR}$ $\left(100 \mathrm{MHz}, \mathrm{DMSO}_{4}-\mathrm{d}_{6}\right) \delta \mathrm{ppm} 39.52,55.22,62.79$, $113.67,128.21,128.82,131.14,134.60,158.36$, IR $3326,1513,1244 \mathrm{~cm}^{-1}$.

\section{4-bromobenzyl alcohol, 2 e}

Yellow powder; $95 \%$ yield; mp $212-215^{\circ} \mathrm{C} ;{ }^{1} \mathrm{HNMR}$ $\left(400 \mathrm{MHz}, \mathrm{DMSO}_{4}-\mathrm{d}_{6}\right) \delta \mathrm{ppm} 4.46\left(2 \mathrm{H}, \mathrm{s}, \mathrm{CH}_{2}\right)$, $5.38(1 \mathrm{H}, \mathrm{s}, \mathrm{OH}), 7.27(2 \mathrm{H}, \mathrm{d}, \mathrm{J}=8, \mathrm{Ar}), 7.48$ $(2 \mathrm{H}, \mathrm{d}, \mathrm{J}=8, \mathrm{Ar}) ;{ }^{13} \mathrm{C}-\mathrm{NMR}\left(100 \mathrm{MHz}, \mathrm{DMSO}_{4}-\mathrm{d}_{6}\right) \delta$ ppm 39.52, 62.40, 62.43, 119.81, 119.83, 128.79, $131.12,142.06$; IR 3272, 1483, $1203 \mathrm{~cm}^{-1}$.

\section{Antibacterial Assay}

\section{Sourcing of Bacteria for Assay}


The bacteria used for the assay were obtained from the Department of Microbiology, Umaru Musa Yar'adua University, Katsina, Nigeria. The Grampositive bacterium, Staphylococcus aureus was cultured in the medium prepared from mannitol salt agar. While the Gram-negative Pseudomonas aeruginosa was cultured in the medium prepared from nutrient agar.

\section{Preparation of culture media}

$50 \mathrm{~g}$ of nutrient agar was dissolved in $1800 \mathrm{~mL}$ distilled water, autoclaved at $121^{\circ} \mathrm{C}$ for 15 minutes, spread into eighty (80) petri dishes and allowed to solidify. The Gram positive and negative bacteria were each inoculated into forty (40) prepared petri dishes (24).

\section{Preparation of the test concentrations}

Twenty milligrams (20 mg) of the compounds were dissolved in $1 \mathrm{~mL}$ of DMSO to afford the stock solution. Using serial double dilution, six different concentrations $\left(10^{-1} \mathrm{mg} / \mathrm{mL}, 10^{-2} \mathrm{mg} / \mathrm{mL}, 10^{-3} \mathrm{mg} /\right.$ $\mathrm{mL}, 10^{-4} \mathrm{mg} / \mathrm{mL}, 10^{-5} \mathrm{mg} / \mathrm{mL}, 10^{-6} \mathrm{mg} / \mathrm{mL}$ ) of each compound were prepared (24).

In vitro assay of the activity of the synthesized compounds on Staphylococcus aureus and Pseudomonas aeruginosa culture

Discs were made from filter paper and dipped into the different concentrations prepared from the five synthesized compounds. The discs were then transferred into the six (6) prepared petri dishes for the Gram-positive and negative bacteria which gave a total of thirty (30) petri dishes for each bacterium. The activity for each compound was determined by measuring the zones of inhibition $(\mathrm{mm})$ of each bacterium after 24 hours of incubation (24).

\section{Molecular Docking studies}

Discovery studio 2018 software was used to investigate the possible orientation and interactions of 2a-e with glucosamine-6-phosphate GlcN-6-P synthase (25). The model structure of GlcN-6-P synthase, ID: 1XFF, was downloaded from the protein data bank. The target protein for molecular coupling was prepared based on the CHARMm force field with help of DS 2018. Structural and energy optimization of $\mathbf{2 a - e}$ as ligands were prepared in DFT/B3LYP/6-31G base set using Gaussian 09 software. The docking studies estimate the binding site in the target model as Glcn-6-p synthase and the affinity of $\mathbf{2 a -}$ e as ligands. CDOCKER was performed to place 2a-e at the selected target binding sites. Docking results were evaluated with three-dimensional amino acid interactions and Binding energy values. Five possible structures of the ligands were generated and the best exposure was defined according to the lowest energy values for each complex.

\section{RESULTS AND DISCUSSION}

\section{Chemistry}

Benzyl alcohol derivatives, 2a-e were synthesized (Scheme 1) by reacting the appropriate aldehyde with the basified solution of sodium borohydride, $\mathrm{NaBH}_{4} / \mathrm{NaOH}(\mathrm{aq})$.
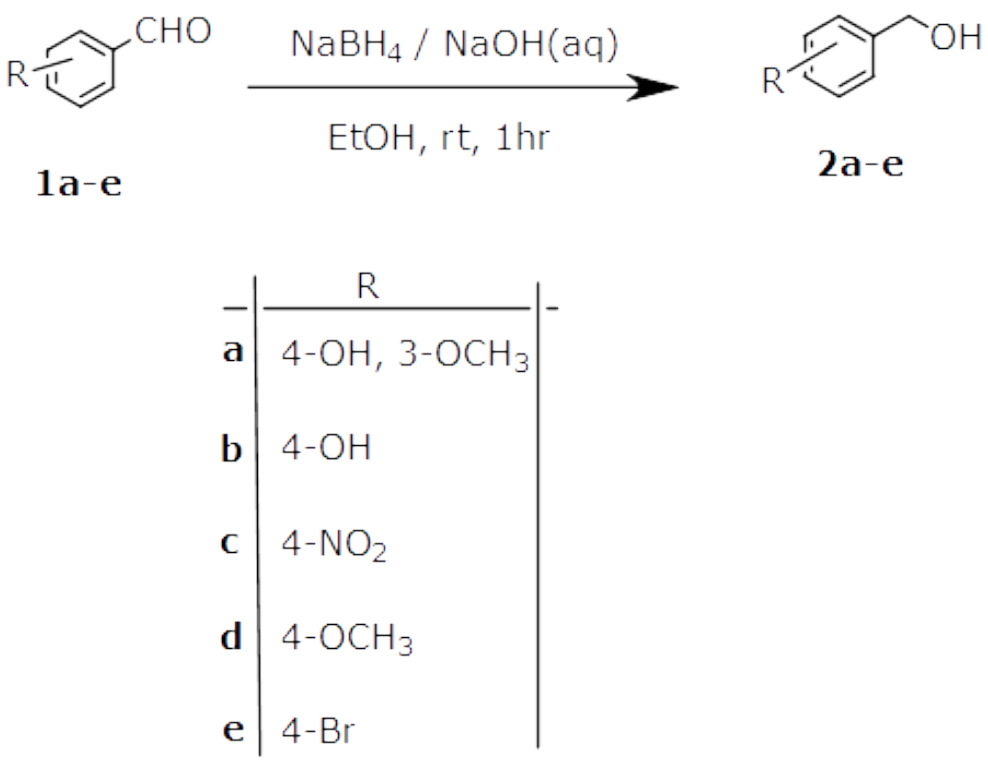

Scheme 1: Synthesis of benzyl alcohol derivatives.

Typically, the $\mathrm{NaBH}_{4}$ solution in aqueous sodium hydroxide was slowly added to the appropriate 
solution of aldehyde in ethanol. The resulting mixture was stirred at room temperature for a few minutes. This was followed with the addition of aqueous $\mathrm{HCl}$ which resulted in the evolution of hydrogen gas signifying the quenching of the excess $\mathrm{NaBH}_{4}$. The corresponding alcohol product precipitated and collected by filtration. After additional washings, the product was air-dried and analyzed. The Nuclear magnetic resonance (NMR) spectroscopic data of compounds $\mathbf{2 a - e}$ revealed the positions as well as the type of the proton and carbon in each compound. While the IR data gave the functional group present, particularly the hydroxyl $(\mathrm{OH})$ functionality. Typically, the ${ }^{1} \mathrm{H}$ NMR spectrum of $\mathbf{2 a}$ revealed a signal at $4.37 \mathrm{ppm}$ assigned to the two protons of the methylene group, $\left(-\mathrm{CH}_{2}\right)$. Further upfield, the signal at 6.70 ppm appeared in the aromatic region of the spectrum and was integrated and assigned to the two aromatic protons closer to the methylene group. The ${ }^{1} \mathrm{H}$ NMR spectrum revealed that the signal at $3.71 \mathrm{ppm}$ was for the three protons of the methoxy group, $\left(-\mathrm{OCH}_{3}\right)$. Also the $-\mathrm{OH}$ proton attached to carbon-1 resonated at $5.14 \mathrm{ppm}$. The ${ }^{13} \mathrm{C}$ NMR spectrum showed a distinct signal at $55.80 \mathrm{ppm}$ which corresponded to the carbon atom of the methoxy group. The signal at $66.36 \mathrm{ppm}$ was assigned to the methylene carbon, while the signals at $111.32 \mathrm{ppm}, 115.35 \mathrm{ppm}, 119.51 \mathrm{ppm}$, $133.72 \mathrm{ppm}, 145.54 \mathrm{ppm}$ and $147.67 \mathrm{ppm}$ were assigned to the carbons of the benzene ring. From the IR spectrum of compound $\mathbf{2} \mathbf{a}$, it was deduced that the band at $3503 \mathrm{~cm}^{-1}$ was due to the $-\mathrm{OH}$ stretching, while the $\mathrm{C}-\mathrm{O}$ stretch (alcohol) was found at $1259 \mathrm{~cm}^{-1}$.

\section{Antibacterial Activity}

The synthesized compounds were screened for in vitro antibacterial activity against Gram-positive and negative bacteria species, Staphylococcus aureus and Pseudomonas aeruginosa respectively using disc diffusion method. The result for the activity was expressed as the length of diameter of the zones of inhibition as given in Table 1.

Table 1: Antibacterial activity of benzyl alcohol derivatives ${ }^{a}$

\begin{tabular}{|c|c|c|c|c|c|c|c|}
\hline \multirow[t]{2}{*}{ Compound } & \multirow[t]{2}{*}{ Organism } & \multicolumn{6}{|c|}{$\begin{array}{c}\text { Zone of Inhibition }(\mathrm{mm}) \\
\text { Conc }(\mathrm{mg} / \mathrm{mL})\end{array}$} \\
\hline & & $10^{-1}$ & $10^{-2}$ & $10^{-3}$ & $10^{-4}$ & $10^{-5}$ & $10^{-6}$ \\
\hline \multirow[b]{2}{*}{$2 a$} & S. aureus & 08 & 00 & 00 & 00 & 00 & 00 \\
\hline & P. aeruginosa & 27 & 11 & 11 & 09 & 08 & 08 \\
\hline \multirow{3}{*}{$\mathbf{2 b}$} & S. aureus & 10 & 00 & 00 & 00 & 00 & 00 \\
\hline & P. aeruginosa & 11 & 09 & 08 & 08 & 08 & 07 \\
\hline & S. aureus & 08 & 08 & 07 & 00 & 00 & 00 \\
\hline 2c & P. aeruginosa & 07 & 00 & 00 & 00 & 00 & 00 \\
\hline \multirow[b]{2}{*}{$2 d$} & S. aureus & 12 & 11 & 11 & 09 & 00 & 00 \\
\hline & P. aeruginosa & 35 & 26 & 23 & 22 & 00 & 00 \\
\hline \multirow[b]{2}{*}{$2 e$} & S. aureus & 00 & 00 & 00 & 00 & 00 & 00 \\
\hline & P. aeruginosa & 12 & 11 & 07 & 00 & 00 & 00 \\
\hline
\end{tabular}

${ }^{a}$ Amoxicillin disc $(30 \mu \mathrm{g} / \mathrm{mL}): S$. aureus $=24 \mathrm{~mm} ; P$. aeruginosa $=13 \mathrm{~mm}$

Generally, the antibacterial activities of all the compounds appeared to be concentration dependant. In the case of Gram-positive bacterium (S. aureus), it was found that at the highest concentration $\left(10^{-1}\right)$, compound $\mathbf{2 d}$ showed a moderate activity $(12 \mathrm{~mm})$. While all other compounds relatively exhibited weak activities. Specifically, compounds $\mathbf{2 b}, \mathbf{2 a}$ and $\mathbf{2 c}$ have 10 $\mathrm{mm}, 08 \mathrm{~mm}$ and $08 \mathrm{~mm}$ zones of inhibition respectively. Compound $\mathbf{2 e}$ did not show any activity at all concentrations. Regarding the Gramnegative bacterium ( $P$. aeruginosa), all of the compounds except 2c exhibited some degree of activities at more than one concentration. It was interestingly found that compound $\mathbf{2 d}$ demonstrated an excellent zone of inhibition (35 $\mathrm{mm})$, and nearly matched the control antibiotic, amoxicillin even at a low concentration of $10^{-3}$ (23 $\mathrm{mm}$ ). Compound $\mathbf{2 a}$ has also showed a better activity at $10^{-1}$ concentration $(27 \mathrm{~mm})$ than the control drug. Overall, it could be commented that compound 2d appeared quite promising as it demonstrated the ability to inhibit the growth of both Gram-positive and negative bacteria.

\section{Molecular Docking Studies}

The enzyme glucosamine-6-phosphate (GlcN-6-P) synthase is responsible for the catalysis of first and rate-limiting step in hexosamine biosynthesis which give rise to uridine $5^{\prime}$-diphospho $\mathrm{N}$ - 
acelglucosamine (UDP-GIcNAC). Considering that UDP-GIcNAC is an essential building block in the fungal and bacterial cell walls, it thus becomes an interesting target for antifungal and antibacterial drug discovery (25).

Amoxicillin as the standard drug binds with GlcN-6$P$ synthase with binding affinity of -169.504 $\mathrm{kcal} / \mathrm{mol}$. The binding sites of amoxicillin on GlcN6-P synthase target included twelve residues involved in the hydrogen bond, five residues involved in hydrophobic interaction and three residues involved in other interactions (Figure 2, left panel). There were two strongest hydrogen bonds that occurred with GLY99 with functional group 016 (bond length $=2.09381$ ) and $\mathrm{H} 27$ (bond length $=2.72711$ ). then with TRP24 through functional group H34 (bond length $=2.7042$ ) and $\mathrm{H} 41$ (bond length $=2.9026$ ). Similarly, another type of hydrogen bond designated as Carbon Hydrogen Bond has also occurred with GLY99 through functional group $\mathrm{H} 43$ (bond length = 2.10665).

The binding of compounds 2a-e to the GlcN-6-P synthase active-site revealed that all the synthesized compounds fitted into the GlcN-6-N active-site receptor cavity, exhibited potential hydrogen-bonding as well as hydrophobic interactions with the proximal amino acid residues (Figure 2, right panel).
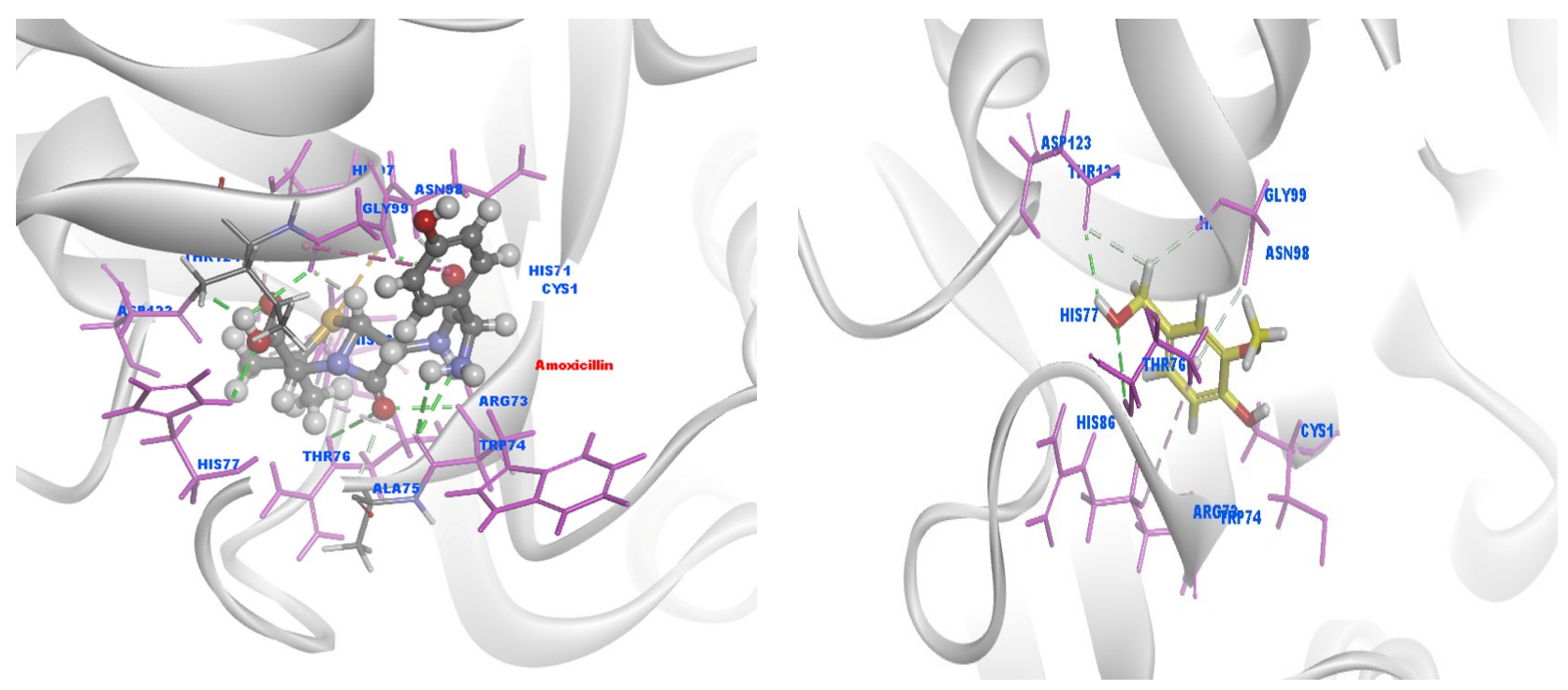

Figure 2. $3 D$ interactions of amoxicillin as reference compound in the GlcN-6-P synthase binding region (left panel); Compound 2a superimposed in the binding site of GlcN-6-P synthase (right panel).

Compound $\mathbf{2 a}$ was found to dock at seven sites (binding energy $=-28.0758 \mathrm{kcal} / \mathrm{mol}$ ). There were two hydrogen bond interactions with ASP123 through functional group $\mathrm{H} 17$ and $\mathrm{H} 15$ (bond length $=2.126$ and 2.874 respectively). Another two hydrogen bonds were revealed with GLY99 through functional groups $\mathrm{H} 15$ and $\mathrm{HN}$ (bond length $=2.300$ and 3.067 respectively). Other types of hydrogen bond as well as the hydrophobic interactions accounted for the remaining binding sites.

Compound $\mathbf{2 b}$ exhibited a total of nine docked interactions (binding energy $=-34.4725 \mathrm{kcal} / \mathrm{mol}$ ). One hydrogen bond with the residue ARG73 through functional group 09 (bond length $=2.456$ ) and hydrophobic interaction with the same residue (bond length $=5.05659$ ) were found. But for the residue TRP74, it was found that the conventional hydrogen bonds have occurred through functional groups $\mathrm{O} 8$ and $\mathrm{H} 16$ (bond length $=2.141$ and
2.55708 respectively). The rest of the interactions have occurred with other residues through various functional groups.

Compound $\mathbf{2 c}$ docked with the enzyme (binding energy $=-66.1382 \mathrm{kcal} / \mathrm{mol}$ ) with lower energy than $2 \mathrm{a}$ and $2 \mathrm{~b}$. This might be due to the fact that there were some residues that each interacted multiple times with the compound. For instance, CYS1 interacted three times using different bonding types through functional groups 017,018 and 019 (bond length $=4.4659,1.86553$ and 3.06222 respectively). Also the residue ARG73 doubly interacted using hydrogen bond through functional group 08 (bond length $=1.87337$ ) and a hydrophobic interaction. Similarly, the residue ASP123 interacted using hydrogen bond through functional groups $\mathrm{H} 15$ and $\mathrm{H} 13$ (bond length = 3.08947 and 2.27452 respectively). In total, there were ten various interactions observed with compound $2 \mathrm{c}$. 
Compound 2d (binding energy $=-52.8901$ $\mathrm{kcal} / \mathrm{mol}$ ) docked at a total of eight sites. It exhibited double interactions with ARG73, a hydrogen bonding through functional group 08 (bond length $=1.87521$ ) and a hydrophobic interaction (bond length $=5.00408$ ). The rest are single interactions with the remaining seven residues.

Compound $2 \mathbf{e}$ docked with the enzyme (binding energy $=-74.6045 \mathrm{kcal} / \mathrm{mol}$ ) at six sites which are fewer than all the compounds. It demonstrated double hydrophobic interactions with the residue HIS86 (bond length $=4.83674$ and 4.91763). The remaining residues interacted singly through various bonding types.

Apparently, in terms of the binding energy, compound $\mathbf{2 e}$ demonstrated the least value $(-74.6045 \mathrm{kcal} / \mathrm{mol})$ second to the standard drug, amoxicillin $(-169.504 \mathrm{kcal} / \mathrm{mol})$. This is in disagreement with the in vitro assay where compound 2d exhibited the best zone of inhibition of the bacterial strains even better than the standard drug. Though it also possessed some significant low binding energy $(-52.8901 \mathrm{kcal} / \mathrm{mol})$. Mismatching of the results of biological assay with the docking studies had been observed in some works. For instance, a standard drug with the most potent in vitro bioactivity was found to exhibit a lesser docking score compared to the tested compounds and vice versa (26). Furthermore, some tested compounds exhibited similar in vitro bioactivities but appeared to differ in their docking results (27).

We opined that these discrepancies might be due to the fact that the tested compounds could be hitting targets other than the enzyme being studied. Other contributing factors might be due to the solubility issues, change in binding conformation of proteins, temperature and ionic strength of the buffer which influence entropy but often neglected in the docking software.

\section{CONCLUSIONS}

Benzyl alcohol derivatives were synthesized using simple $\mathrm{NaBH}_{4}$ reduction. Although the compounds are known, but for the first time, their antibacterial activities have been investigated. And the results demonstrated that the activity was concentration dependant, and that the compounds were generally potent against $P$. aeruginosa. Only two of the compounds were active against $S$. aureus. In terms of broad spectrum activity, compound $\mathbf{2 d}$ was found to exhibit a promising efficacy which surpassed that of the standard drug. In order to understand the mode of interaction of the compounds, an in silico studies were carried out by docking the compounds against glucosamine-6phosphate synthase (GlcN-6-P) as potential target. Interestingly, all the compounds fitted into the cavity and demonstrated a close alignment of the ligands with the enzyme active site. Of note was the binding energy of the most biologically active compound, 2d which appeared to have a relatively favorable binding energy.

This work recommends further studies on the pharmacokinetic properties of compound $\mathbf{2 d}$. Based on the information obtained, it may also be subjected to in vivo studies to fully explore its potential as a possible lead that could be optimized to clinical trials in order to have a new antibacterial agent.

\section{ACKNOWLEDGEMENT}

Kabir Yahuza, Department of Microbiology, Umaru Musa Yar'adua University, Katsina, Nigeria is gratefully acknowledged for the antibacterial assay.

\section{REFERENCES}

1. Theuretzbacher $U$, Mouton JW. Update on antibacterial and antifungal drugs - Can we master the resistance crisis?. Current Opinion in Pharmacology. 2011;11: 429-32.

2. Walsh T, Toleman M. The emergence of panresistant gram-negative pathogens merits a rapid global political response. Journal of Antimicrobial Chemotherapy. 2012;67:1-3.

3. Awouafack MD, McGaw L], Gottfried S, Mbouangouere $R$, Tane $P$, Spiteller M, Eloff JN. Antimicrobial activity and cytotoxicity of the ethanol extract, fractions and eight compounds isolated from Eriosema robustum (Fabaceae). BMC Complementary and Alternative Medicine. 2013;13:1.

4. Srivastava J, Chandra H, Nautiyal AR, Kalra SJS: Antimicrobial resistance (AMR) and plant-derived antimicrobials (PDAms) as an alternative drug line to control infections. Biotechnology. 2013;4:45160.

5. Neu HC. The crisis in antibiotic resistance. Science. 1992;257:1064-73.

6. Lowy F. Antimicrobial resistance: the example of Staphylococcus aureus. Journal of Clinical Investigation. 2003;111:1265-73.

7. Varshney V, Mishra NN, Shukla PK, Sahu DP. Synthesis of nitroimidazole derived oxazolidinones as antibacterial agents. European journal of medicinal chemistry. 2010;45(2):661-6. 
8. Gupta K, Pandeya SN, Pathak AK, Gupta A. Synthesis and Antibacterial Activity of Ciprofloxacin Derivatives. Research Journal of Pharmacy and Technology. 2011;4(2):308-14.

9. Ye FQ, Ding YM, Chen $L$, Ye S, Chen ZX. Synthesis and antibacterial activity of ciprofloxacin derivatives. Acta pharmaceutica Sinica. 2005;40(2):132-5.

10. Mokaber-Esfahani $M$, Eshghi $H$, Akbarzadeh $M$, Gholizadeh M, Mirzaie Y, Hakimi M, Lari J. Synthesis and Antibacterial Evaluation of New Pyrimidyl N-Ciprofloxacin Derivatives. ChemistrySelect. 2019;4(31):8930-3.

11. Rabbani MG, Islam MR, Ahmad M, Hossion AM. Synthesis of some $\mathrm{NH}$-derivatives of ciprofloxacin as antibacterial and antifungal agents. Bangladesh Journal of Pharmacology. 2011;6(1):6-13.

12. Wang $A, X u$ Y. Synthesis and antibacterial activity of novel icariin derivatives. Die PharmazieAn International Journal of Pharmaceutical Sciences. 2019;74(2):73-8.

13. Nitbani FO, Siswanta D, Sholikhah EN, Fitriastuti D. Synthesis and antibacterial activity 1monolaurin. Oriental Journal of Chemistry. $2018 ; 34(2): 863$

14. Albert S, Horbach R, Deising HB, Siewert B, Csuk R. Synthesis and antimicrobial activity of (E) stilbene derivatives. Bioorganic \& medicinal chemistry. $2011 ; 19(17): 5155-66$.

15. Zhang HZ, He SC, Peng YJ, Zhang HJ, Gopala L, Tangadanchu VK, Gan LL, Zhou CH. Design, synthesis and antimicrobial evaluation of novel benzimidazole-incorporated sulfonamide analogues. European journal of medicinal chemistry. 2017;136:165-83.

16. Tiwari B, Pratapwar AS, Tapas AR, Butle SR, Vatkar BS. Synthesis and antimicrobial activity of some chalcone derivatives. International Journal of ChemTech Research. 2010;2(1):499-503.

17. Elenich OV, Lytvyn RZ, Blinder OV, Skripskaya OV, Lyavinets OS, Pitkovych Kh E, Obushak MD, Yagodinets PI. Synthesis and Antimicrobial Activity of 3-Phenyl-1-Methylquinolin-2-One Derivatives. Pharmaceutical Chemistry Journal. 2019; 52, 969-974.

18. Shingate BB, Hazra BG, Salunke DB, Pore VS, Shirazi F, Deshpande MV. Synthesis and antimicrobial activity of novel oxysterols from lanosterol. Tetrahedron. 2013;69(52):11155-63.
19. Paola V, Athina G, Kitka A, Matteo I, Franca Z, Synthesis and antimicrobial activity of novel 2thiazolylimino-5-arylidene-4-thiazolidinones.

Bioorganic \& Medicinal Chemistry. 2006;14(11),3859-3864.

20. Kumar KP, Vedavathi $P$, Subbaiah $K V$, Reddy DV. Design, synthesis, spectral characterization and bioactivity evaluation of new sulfonamide and carbamate derivatives of 5 -Nitro- $1 \mathrm{H}$-indazole. Organic Communications. 2017;10(3):239-249.

21. Abdel-Rahman RM, Ali TE. Synthesis and biological evaluation of some new polyfluorinated 4-thiazolidinone and a-aminophosphonic acid derivatives. Monatshefte für Chemie-Chemical Monthly. 2013;144(8):1243-52.

22. The Merck Index: An Encyclopedia of Chemicals, Drugs, and Biologicals (11th ed.), Merck, 1989, ISBN 091191028X, 1138.

23. NACDG Allergen: Benzyl alcohol. https://www.the-dermatologist.com/article/7191 (accessed May 4, 2020).

24. Barakat A., Al-majid A.M., Shahidul M.I., Warad I., Masand V.H, Yousuf S., Choudhary M.I. (2016). Molecular structure investigation and biological evaluation of Michael adducts derived from dimedone. Research on Chemical intermediates. 2016; 42(5): 4041-4053.

25. Borowski E. Novel approaches in the rational design of antifungal agents of low toxicity. Farmaco. 2000; 55:206-208.

26. Patel MM, Patel LJ. Synthesis, molecular docking and antibacterial evaluation of some novel fluoroquinolone derivatives as potent antibacterial agents. The Scientific World Journal. 2014.

27. Alam MS, Jebins S, Rahman MM, Bari Md L. Biological and quantitative SAR evaluation and docking studies of (E)-N-benzylidebenzo hydrazide analogues as potential antibacterial agents. EXCLI Journal. 2016; 15, 350-361. 
